\title{
The Chai Point ACQT: Brewing Tradition and Technology for Success
}

\section{OPEN ACCESS}

Manuscript ID:

MGT-2021-09014066

Volume: 9

Issue: 1

Month: July

Year: 2021

P-ISSN: 2321-4643

E-ISSN: 2581-9402

Received: 29.04.2021

Accepted: 02.06.2021

Published: 01.07.2021

Citation:

Nair, Sindhu Shantha, and SP Smritika. "The Chai Point ACQT: Brewing Tradition and Technology for Success." Shanlax International Journal of Management, vol. 9, no. 1, 2021, pp. 17-19.

DOI:

https://doi.org/10.34293/ management.v9i1.4066

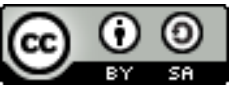

This work is licensed under a Creative Commons Attribution-ShareAlike 4.0 International License.

\section{Sindhu Shantha Nair}

Christ University, Karnataka, India

https://orcid.org/0000-0003-1680-716X

\section{S. P. Smritika}

Canada

Abstract

The unique selling proposition of Chai Point was a combination of Access, Convenience, Quality and Turnaround time (ACQT). The route map of Chai point is quite interesting; in 2009, the idea surfaces, 2010 it becomes a reality and by 2011, around 10 Chai Point Stores are opened in Bangalore, 1 million chai cups were sold and add-on products like Vada Pao and Samosa were introduced. In 2014, Chai on call, Website, mobile app were launched and went on cloud. In 2015, Fidelity invests \$10mn and in 2016, PrioriTea mobile wallet, reward program and boxC were launched. By 2017 they were able to open 97 outlets across Bangalore and are venturing into other cities. The growth propositions of Chai Point were innovation and consistency.

Keywords: Chai point, Tradition, Technology

\section{Introduction}

Chai Point initiative was to brand the very common yet the most sought after product in India, 'Chai' under the slogan "India runs on Chai". India especially Bangalore had many cafe's but very few Chai joints. People used to flock cafe's due to lack of quality joints for Chai. Chai Point found the untapped area and brought its quality tea to customers and they could have it on the go at the airports, or in business or office. They made this possible by merging tradition and technology. They have an efficient technology management strategy and supply chain which is evident in the customer reviews. The Proprietary Shark point of sale (POS) system helps Chai Point to manage the processes, from placing orders, collecting payments, capturing customer information, supply chain management, actionable insights and viewing reports, spending capacity, and to develop individual strategies for customising the needs of customers. The machine learning engine Shark ML is used to predict demand at retail stores, plan inventory, and manage and prevent loss of revenue. The proactive method to eliminate repair and maintenance is practiced at Chai Point to enhance customer experience and reduce revenue loss. The problems of over-stocking and pilferage are overcome by an app in boxC machines through need based orders that can be placed by facility managers.

\section{Cloud Immersed in 2016}

Chai Point (2016) launched Internet of Things (IoT) enabled systems called boxC. This cloud brewing move, powered by Shark platform, equipped Chai Point with smart devices connected to the cloud to capture signals from vending machines to send real-time data to the Cloud and redirect the same to clients via the dashboard of customer relationship management (CRM). 
The quality of Chai is maintained through optimum brewing and flushing cycle. The Founder and CEO of Chai Point, Amuleek Singh believes that for a business to be viable, the inflow of the volume of customers and average purchase order sizes are crucial. His view is that these two aspects and store by store attention on a constant basis pave way for the business expansion. Chai point considers the privacy and need of smoking and non-smoking customers by providing space for both. The consistency of quality is maintained to build and retain customer loyalty. The customer ease and satisfaction was further expanded through mobile-based application with adequate information of the products available, and to place orders from nearby outlets with lots of freebies and discounts.

The Vision of Chai Point is for the working India to create retail chain, with true value orientation, to be beverage focused and build a brand around the liquid chai. Chai Point does not offer a basic franchise model, instead offers a core aspect of employment value proposition through Partner Franchise Model in which best employees will be given an option to own Chai Point Franchise. This model would help faster expansion with high calibre units of Chai Point through loyal employees.

Marketing strategy of Chai Point is branding the common product to create an impact without much alteration of the product. The 5 pillars are the $5 \mathrm{C}$ 's of Chai Point; Customer Sales (C1), Chai Quality (C2), Customer Services (C3), Cleanliness (C4), and Chai Point ethics \& environment (C5).

Green T-Brigade: The delivery fleet of Chai Point consists of electric scooters deployed across all cities with the fleet saving fuel, keeping air pollution levels low in and around all its locations. The innovative light weight, heat resistant disposable flask is also completely recyclable, making Chai Point the first beverage outlet with $100 \%$ biodegradable packaging.

Threat of competition: One of the biggest perceived rivals of Chai Point is Infinitea, which generates $\$ 3.8$ million more in terms of revenue. Other competitors are Chaipatty which is also headquartered in Bangalore and generates $33 \%$ more in terms of revenue, and Chaayos with more employees catering to non-alcoholic beverages.

\section{Conclusion}

Expanding the presence, Chai Point holds the credit of being the first company to deliver a hot beverage at doorstep in a heat retaining disposable flask, available in different volumes with the capacity to retain heat for around 60 minutes approved for food industry usage and certified free of harmful BPAs. Training curriculum and programs for authentic chai brewing is provided by Mountain Tail Academy (MTA) and MTA sources, trains, tests and certifies all employees at Chai Point. Currently Chai Point operates in eight Indian cities across retail locations, airports and business parks physically along with online services of "Chai-on-Call". In 2017, Chai Point started selling teas on Amazon.in, foraying e-commerce platform. Year on year growth of $50 \%$ with estimated annual revenue of $\$ 7.5 \mathrm{M}$, through smart technology and supply chain powered by machine learning are expected. With 97 locations and 1200+ employees as of 2017, within a span of 7 years Chai Point has proved its ACQT beyond doubt brightening customer experiences of Chai.

\section{Key Learning Points}

- The CEO can play a powerful role in reinforcing expectations and cascading information to their teams

- Setting up local units and champions helps to disseminate business messages

- Active listening to customers, enhancing customer experiences to make their days brilliant will get you customer loyalty

- Providing professional training to employees will empower them

- Less is more: concentrating on fewer products with high quality proves worthy than having more with low quality

- A helicopter view of where the company is headed motivates, inspires, and energizes employees to take business to greater heights with a clear vision and future direction of the company and also enables the employees to see 'what is in it for me'

- Innovative, State-of-the-Art technology can reinforce, strengthen and empower business.

- Technology is not an add-on or feature for the core offering any more; it is an enabler to smoothly 
deliver core offering to the valued customer.

- Employee value proposition through employee ownership brings in loyalty and commitment from best employees to expand business

- Branding with congruence of key external and internal messages takes business a long way

- Values underpin the way an organization does business

- Employee engagement has to be integrated into the measuring systems

- Making managers accountable for engagement scores in their areas will prove successful for business

- Employee development and strategic tuning is an essential step for employee engagement

- Learning \& growth, internal business processes, customer service satisfaction, and financial performance (balanced scorecard) as a management system broadens the measure of corporate health beyond profit to customers and people satisfaction.

- Budding entrepreneurs need to methodically look for opportunities to tap the untapped niche area

- Entrepreneurs are not merely risk takers but they need to measure risk-takers.

- Achieving success is not the key in business; rather it is sustainability in the mass market.

- Optimizing and building fundamental pillars are crucial for start-ups

- Start-up through visionary leadership can build strong companies with highest level of customer satisfaction through quality products in an ethical, green friendly environment, true to its value orientation.

\section{References}

Ahmad, Samreen. "How Tea Chains are Using Chai Bots to make the Cuppa of your Choice." Business Standard, 2019.

Balram, Smita. "Chai Point Enters Instant Tea Market as Work From Home Remains Strong among Millennials.” Retail.com, 2021.

"Chai Point." Owler, https://www.owler.com/ company/chaipoint

"Chai Point." Wikipedia, https://en.wikipedia.org/ wiki/Chai_Point

"Chai Point Brews a Strong Case for Technology which Helps bring you the Perfect Cup of Tea." Your Story, 2017, https://yourstory. com/2017/11/chai-point-technology-perfecttea

Cook, Sarah. The Essential Guide to Employee Engagement: Better Business Performance through Staff Satisfaction. Kogan Page, 2008.

Narasimhan, T.E. "Chaayos, Chai Point: Branding Tea for the Millennial." Business Standard, 2017.

Sheikh, Aminah. "Chai Pe Charcha with the Man Who Brewed the Idea of Chai Point - India's Largest Tea Retail Chain.” Better India, 2016.

\section{Author Details \\ Dr. Sindhu Shantha Nair, Christ University, Karnataka, India, Email ID: sindhusonnet@gmail.com.}

S. P. Smritika, Canada, Email ID: smritika.s.prem@gmail.com. 